\title{
タテツツガムシ幼虫の数種ネズえ類に 対する寄生態度の差異について
}

（恙虫の研究 第 94 報）

\author{
Observations on the differences in the species of \\ some rodents as the hosts of Tsutsugamushi, \\ Trombicula scutellaris Nagayo et al., 1921
}

\author{
田中寬 ${ }^{11}$ 長田泰博 ${ }^{11}$ 上野庸治 ${ }^{22}$ \\ Hiroshi Tanaka, Yasuhiro Osada and Yoji Ueno
}

\section{はしがき}

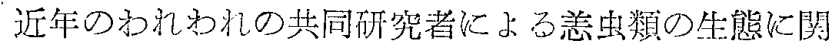
する研究の進展炕をもなつて, その幼虫の宿主選択性の 問題が次第飞解明されて来た. 即占, 恙虫纱虫のある種

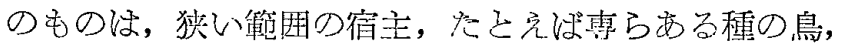

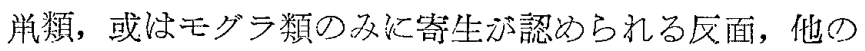

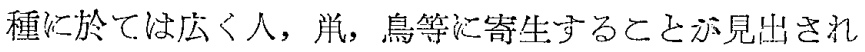

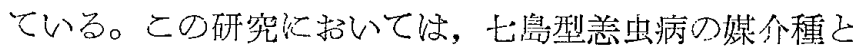
して注目されているタテツ>ガムシ Trombicula scutellaris Nagayo et al., 1921kついて奏駼的に 4 種の単蛋 用い，その宿主性の差異学検討した。タテッッガムシは

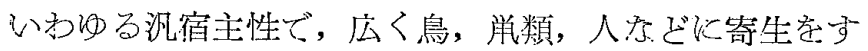

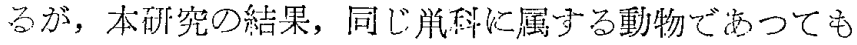
ハタネズミと，他の3種この間に生理・生態的飞宿主已

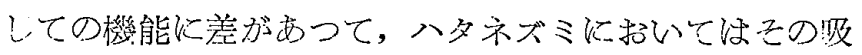
着淦腹する率が高く, しかも吸着時間が長いこ己が判明 し灾.

\section{実験方法}

八丈島飛行場附近の林の中で岩角に集つている恙虫京

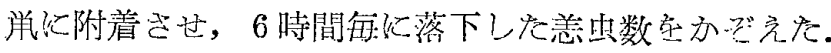

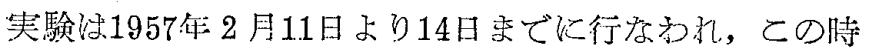
期飞同地区《出現する恙虫幼虫深 Tr. scutellaris が殆ん ぞでわずが Tr. pallida burnsi が採集された。使用 した学注東大伝研獣㾤研究部で飼育繁殖させているマウ ス Mus musculus, ラッテ Rattus norvegicus, 八タネズ $ミ$ Microtus montebelli, スナネズミ Meriones unguicul-

1）東京大学伝染病研究所笴生虫研究部 Dep. of Parasit., Institute for Infectious Diseases, University of Tokyo

2）八大島三根搒療所 Mitsune Hospital, Hachijo Island atus A. Milne-Edwaids, 1868 の 種で㳊つた.

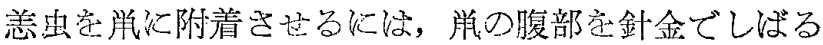
か，光の一脚にひもをつないで歩行させる方，或は值接 爯を寿でつかんで岩の上の恙虫幻出の集落にとすりつけ

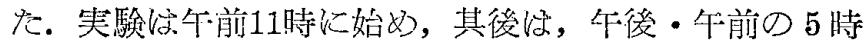

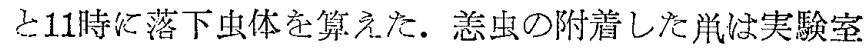

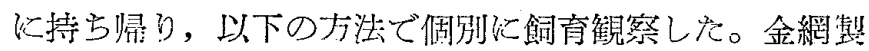
のかごに觉を入れ，をの關口部学目の細かい全網で覆つ て, 下向にし，己の下部に金属漏斗学㑬け，金体学钩下 げ，漏斗の下に水を入彻たシャーレ学置いた，との装置 で宿主より離れた恙虫はシヤーレに集つてくるが，虫体 を算える前に社漏斗の内壁学水を流して洗い，と〉に留

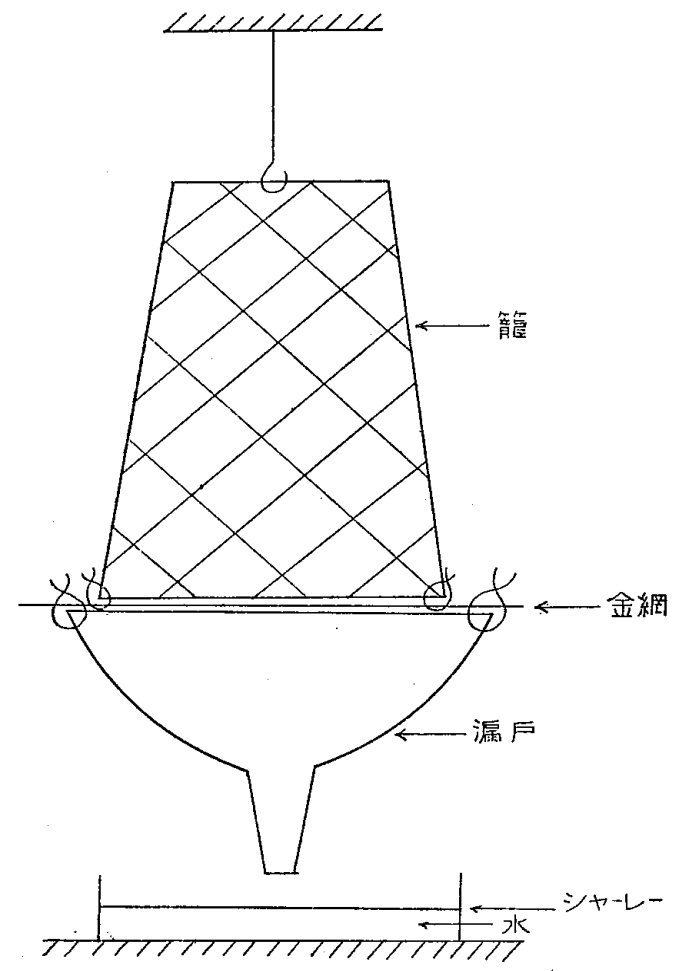

四 
表 1 宿主別の落下恙虫幼虫数の時間的経過

\begin{tabular}{|c|c|c|c|c|c|c|c|c|c|c|c|c|c|c|}
\hline 宿 & 主 & & $\nabla$ & x & & ラ & $\%$ & 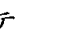 & & ーネス & & & 又ネ & \\
\hline \multicolumn{2}{|c|}{ ネズミ番号 } & 1 & 2 & 3 & 4 & 1 & 2 & 3 & 1 & 2 & 3 & 1 & 2 & 3 \\
\hline \multirow{14}{*}{$\begin{array}{l}\text { 恙 } \\
\text { 虫 } \\
\text { 附 } \\
\text { 差 } \\
\text { 後 } \\
\text { の } \\
\text { 経 } \\
\text { 過 } \\
\text { 時 } \\
\text { 間 }\end{array}$} & 6時間 & 126 & 67 & 39 & 190 & 466 & 724 & 275 & 524 & 443 & 290 & 166 & 30 & 33 \\
\hline & 12 & 22 & $\mathbf{5}$ & 一 & 17 & 31 & 42 & 4 & 23 & 79 & 19 & $\begin{array}{r}14 \\
1\end{array}$ & 1 & 4 \\
\hline & 18 & 2 & $\begin{array}{l}\mathbf{5} \\
1\end{array}$ & 6 & 17 & $\begin{array}{r}30 \\
3\end{array}$ & $\begin{array}{l}18 \\
10\end{array}$ & $\begin{array}{r}24 \\
4\end{array}$ & $\begin{array}{r}13 \\
2\end{array}$ & $\begin{array}{r}\mathbf{3 1} \\
5\end{array}$ & $\begin{array}{r}14 \\
4\end{array}$ & $\begin{array}{r}6 \\
10\end{array}$ & 3 & $\mathbf{1}$ \\
\hline & & 6 & 3 & & 11 & 4 & 5 & 7 & 19 & 8 & $\mathbf{1}$ & & & 1 \\
\hline & 24 & 2 & 25 & 5 & 1 & 21 & 39 & 34 & 39 & 67 & 114 & 3 & 1 & 1 \\
\hline & 30 & $\begin{array}{r}\mathbf{1} \\
20\end{array}$ & 69 & 36 & 88 & 417 & 401 & 196 & $\begin{array}{r}\mathbf{5} \\
162\end{array}$ & 287 & 208 & 16 & 9 & 3 \\
\hline & 36 & 8 & 25 & 8 & $\begin{array}{r}\mathbf{1} \\
58\end{array}$ & 103 & $\begin{array}{r}2 \\
196\end{array}$ & $\begin{array}{r}\mathbf{3} \\
133\end{array}$ & 116 & 240 & 278 & 5 & 12 & 死亡 \\
\hline & 42 & 3 & 14 & 11 & 45 & 91 & 162 & 172 & 115 & 91 & 204 & 26 & 19 & 65 \\
\hline & 48 & 1 & 7 & 8 & 24 & 123 & 75 & 59 & 71 & 37 & 49 & 18 & 28 & 258 \\
\hline & 54 & 4 & 4 & 7 & 26 & 131 & 100 & 62 & 72 & $\begin{array}{r}4 \\
91\end{array}$ & 120 & 11 & 56 & 143 \\
\hline & 60 & 0 & 0 & 4 & 9 & 33 & 38 & 35 & 25 & 14 & 27 & 1 & 16 & 35 \\
\hline & 66 & 2 & 3 & 2 & 9 & 1 & 7 & 16 & 5 & 3 & 45 & 4 & 10 & 9 \\
\hline & 72 & 0 & 3 & 4 & 4 & 11 & 14 & 5 & 14 & 24 & 27 & 3 & 16 & 1 \\
\hline & 78 & & & & & & & & 1 & & 3 & 1 & 23 & 8 \\
\hline 残 & 留 & & & & & & & & & & & 14 & 80 & \\
\hline
\end{tabular}

つている恙虫もシヤーレに洗い落した（図1）.

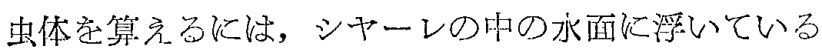

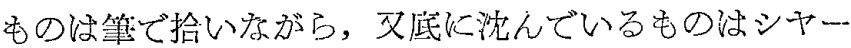

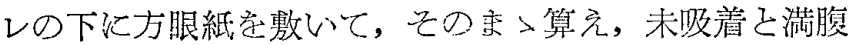

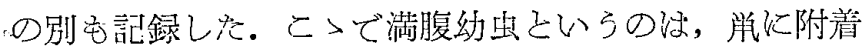

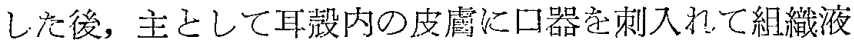
空吸い，満腹して体が大きくり，笴生の目的定達した むのであり，又未吸着幼虫は觉の体飞一たんは附着して も笑際に浪膚に吸着せずに落されてしなつたすの学さ しこの両者は体の形や大きさできすく区别しら白光 のである.

\section{実験 結果}

こ5して観察した結果赾表 1 《示し，各種別の計定図 2 亿示した。附着した恙虫の弓点最初の6 時間内飞相当 数功吸着せずに落下し，未吸着幼虫の落下は其後念に少 くなり拣さ30㭙間後には終了した。満腹测虫の落下はマ ウス，シッテ，スナネズミに於いてい12〜18時間俊に始 壳り，30㭙間後以最大さなり，72〜78時間前後で殆んざ 落下し終り，耳殸内に恙虫の残留は認好㞦なかった。 八タネズミの場合は落下正当満腹幼虫の最大になる山が

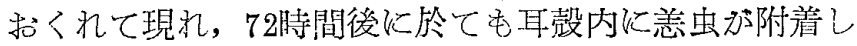
て招り，全部の幻忠が吸着し終る時間はさらに相当延原
するととが認められ\%，各種の莄主火ついて，水面に落 下した，満腹・沫吸着幼出の比率の一㤹性学 $\chi^{2}$ 検定法で 検定すると（表 2) $\chi_{[3]}^{2}=143.21$ こなり，差は著るしく 有意己なつた。即ち满腹幻虫の比率はハタネズミで大き く，マウスでは小さいここが見引けられた。のの結果》 らハタネズミでは附着した善虫幼虫の中吸着するものが 多く，又耶殸居る時間も長いここが分つた。

\section{考 察}

以上の観察で，ハタネズミ快他の 3 種に比してタテッ ツガムシ纤虫の満腹率方高いここと，その吸着時間が平 均して長いととが明らかになつたが，乙の事奏は，佐从 (1956) の綜説に述べられているよに，こ机宋での自 然界の钼察で，色々な種類の恙虫についてハタネズミが アカネズミなどより多くの恙虫宔寄坐さやているこいう

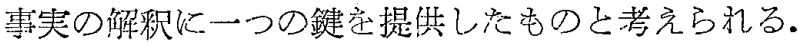

第 1 の，八タネズミに満腹率が高いこいう現象は少く もその一部に括いて䋃の動作の差が原因りているこ思わ

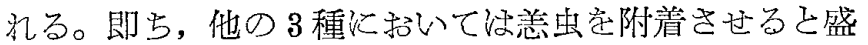

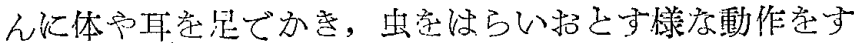

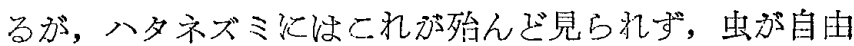

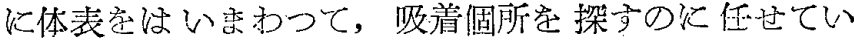

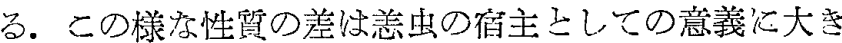


表 2 宿主別恙虫未吸着, 満腹幻虫の比率の比較検定

\begin{tabular}{|c|c|c|c|c|c|}
\hline 末 盖別 & マウ & $\widetilde{\sigma}$ & スナネズミ & ハタネズミ & 計 \\
\hline 末吸着 & $518(391.46)$ & $1635(1600.99)$ & $1469(1490.73)$ & $259(397.38)$ & 3881 \\
\hline 満 & $540(666.54)$ & $2692(2726.01)$ & $2560(2538.27)$ & $815(676.62)$ & 6607 \\
\hline 計 & 1058 & 4327 & 4029 & 1074 & 10488 \\
\hline
\end{tabular}

（）内は理論值
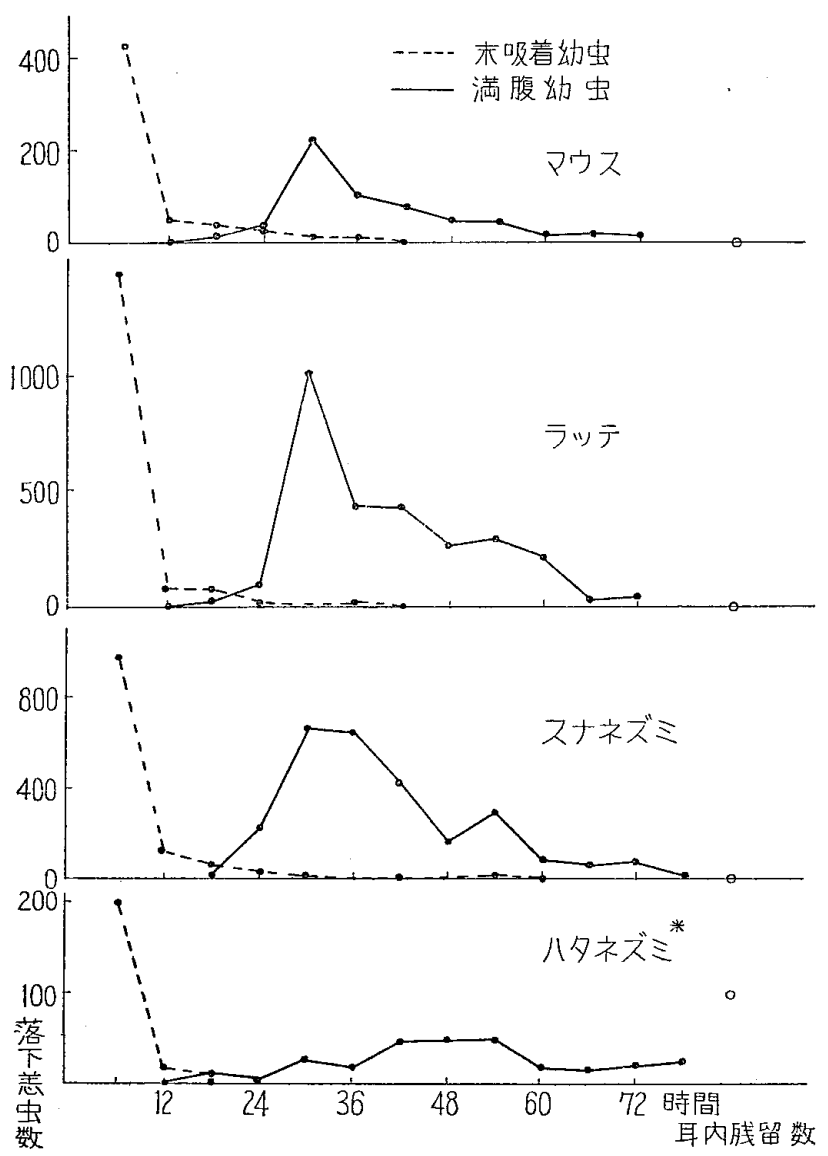

図 2 缩主より落下しえ恙虫数の時閒的消長 *ハタネズミは 1 匹死ししているので 2 匹の計

な相違をもたらすものであろう。

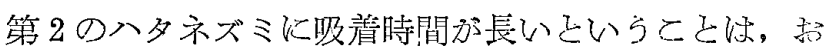
そらく皮膚の生理的ないし形態的な構造の差にもとづい て，虫の満腹に長封間要要与るため已考光々れる。しの 事军は，店已え同数の虫が附着したさしても，八タネズ ミは他の舭飞比して捕獲観察㭙には多数の虫方見出され るこさ意味する。

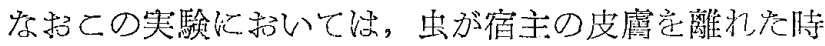
期学観察したものではなく，さら水装置の中で，単の

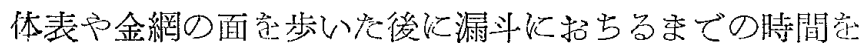

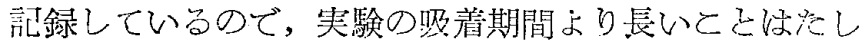

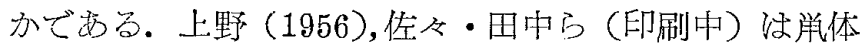
の直接の観察により，実験的にラッテにタテッッガムシ
幼虫学附着させると，凡气 42 時間後には満腹宝完了して 耳内烛虫が残つていないとと定報告しているが，今回 観察された満腹洔間がこれより長いの注以上の理由に上 る己推定される。

\section{まとめ}

1.八丈島に於て 4 種の爯，八タネズミ，マウスラッ テ，スナネズミ学 Tr. scutellaris 幼虫の集落上学はわ先 て実験的飞附着させ， 6 時間每《宿主より落下する恙虫 幼虫数の時間的な消長学末吸着・満腹幼虫別に調べた。

2. マウス，ラッテ，スナネズミでは恙虫幼虫学附着 させてから，初め怔未吸着幼虫が落ち，12時間後より满 腹纤虫が落下乙始め 30 時間で落下満腹幼虫数は最高にな り，78時間後密でには落下し終り，耳款内に残留幼虫安 認めなかつた。

3.八タネズミでは未吸着幼虫は同様に早く落下ずる が満腹幼虫証他の宿主の場合と異り，約 1 日拉くれて落 下数が最高になり，78時間後でも耳款内に吸着している あのが認められ，平均して吸着㭙間の長いことが判明し \%. 又他の宿主に比へ，全附着数に刘寸る満腹幼虫の率 が大であつた。

4. 以上の様に汎寄生性のTr. scutellaris に於ても宿 主により寄生の態度が異るとこが実験的に判明した。 又 八タネズミに於て, 満腹する幼虫数が多く, 吸着㭙間が 長いここが分つた。このととは自然界で恙虫の宿主紪類 を捕獲した場合ハタネズミに特に多数の寄生を認めてい た事実の一端学解明した。

稿を閉るに当り御指尊を賜わった東大伝研等生虫部， 佐々学助教授飞厚く感謝の意を表す。

\section{主要文献}

1) 佐々学 $(1956)$ : 恙虫已恙虫病 $497 \mathrm{pp}$. 医学書院. 一2）佐々学・田中寬・上野唐治・三浦昭子・林滋生 鈴木猛・田中英交(印刷中)：八丈地方に和ける夏型 恙虫類の生態化関する研究. 七島熱の研究 IV. 東京 都. 一3）上野庸治 (1956)：八丈島の恙虫子恙蚔病の 研究, 衞生動物 $7(3 \cdot 4): 231-253$ :

\section{Summary}

Observations on the differences in several species of rodents as the host of Trombicula scutel-. laris were made in February, 1957, at Hachijo. 
Island, south of Tokyo, where Shichito-type Tsutsugamushi disease was prevalent. Four species of rodents, Mus musculus (laboratory white mouse), Rattus norvegicus (laboratory white rat), Microtus montebelli and Meriones unguiculatus were used as the experimental hosts for comparison. As was reported in the previous papers, unengorged larvae of Trombicula scutellaris were found to form clusters on the soil surface, especially on tops of rocks or stones, in very season of the year. Infestation of the mites on the hosts were caused by contacting the rodents directly with the clusters. The hosts were kept separately in cages shown in Fig. 1, and the number of mites dropped off from hosts were counted every 6 hours. From Mus,
Rattus and Meriones, considerable numbers of unengorged larvae were recovered during the first 6 hours, and engorged larvae could obtain between 12 to 78 hours, with a peak at 30 hours. In the case of Microtus, the time required for engorgement of larvae was found to be considerably longer than in the former species, and the peak appeared about 24 hours later, some being still attached even after 78 hours. The ratio of number of engorged larvae to the unengorged one was also higher in Microtus than in the other species. The results seem to have solved at least a part of the question why Microtus in the fields harbour more mites than other rodent species collected. in the same localities.

\title{
野鬼に寄生する恙虫類並びにその 1 新種 Gahrliepia (Walchia) masoni の記載
}

\author{
Notes on chigger mites found on the Japanese hares, with \\ a description of Gahrliepia (Walchia) masoni n.sp.
}

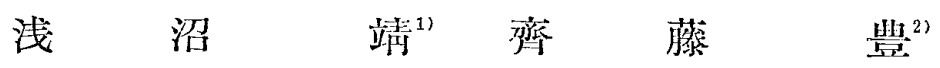

Kiyoshi Asanuma and Yutaka Saito

野鬼に奇生する善虫類については，すでに安藤その他 （1953）の報告があり，浅沼乞の他（1955）も追加する こころがあつたが, その後さらに, 干葉, 静岡, 埼玉, 福島, 東京, 神奈川, 山梨, 新潟の各地に抬いて, かな りの資料孛らることができたので，ととに改めて発表字 行いたい。な招，前にWalchia sp. ¿して，浅沼加記録 して抒いた恙虫は，その後，新潟県です多数個体が採集 され，調查の結果，未記載種であるここ学知つたので， この機会に併せて新種として報告して扔く.

本文に入る前に, 御指尊, 御鞭撻学賜つた田宮猛雄, 北岡正見両博士並びに伊藤泰一，伊藤辰二両教授，材料 の入手に梅協力下されれ千葉大学医学部細菌学教室の 桜井信夫博士，大原綜合病院の大原嘗一郎博士，東京交 化医学技術学校の利岡静一氏，並びに高昰武夫，後藤侗

1）凟源科学研究所（業績第 844）

Research Institute for Natural Resources

2) 新潟大学医学部細菌学教室

Dept. of Bacteriology, Niigata University

School of Medicine
德, 中川宏, 泟口豊治, 宮本武美の諸氏に厚く御礼申上，

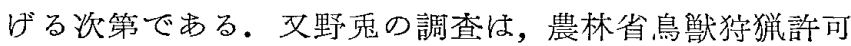
のもとに行われれもので, 御高配に与つそ葛精一課長, 小楖和助氏に名感謝の意を表わさして戴きたい。

\section{I. 新種の記載}

とつでは, 前に Walchia sp. として招い布種字 Gahrliehia 属 Walchia 亜属のものとして扱うが, この善:

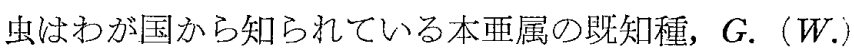
ogatai 己は，背甲板，第 3 脚基節毛，その他の特徵によ り，容易に区別するとこがでさる。

Gahrliepia (Walchia) masoni n. sp.

生時の体色(但し満腹又心゙それに近い状態の個体)は， わが国の普通種 G. (G.) saduski 己虻異り, 淡紅色で, や>黄味括び, 丽腹個体では, 体長約 $730 \mu$, 体巾約 $540 \mu$ 字数える. 歩脚の節数は, 前肢 7 節, 中・後肢 6 節で, Gahrlipiinae の特幑㞭示す. 背板毛は前側毛, 後側毛及げ感覚毛の3 対のみで, 正中毛及び副毛肎欠き 